\title{
First data on Cicadas of Kefalonia, Greece (Hemiptera: Cicadidae), including bioacoustics
}

\author{
Первые сведения о цикадах (Hemiptera: Cicadidae) острова \\ Кефалония, включая биоакустику
}

\author{
Tomi Trilar ${ }^{1}$, Matija Gogala ${ }^{2}$, Francesca Graziani ${ }^{3}$, \\ Filippo Ceccolini ${ }^{3}$, Fabio Cianferoni ${ }^{3,} 4^{*}$
}

\author{
Т. Тримар ${ }^{1}$, М. Гогала ${ }^{2}$, Ф. Грациани ${ }^{3}$, Ф. Чекколини \\ Ф. Чианферони ${ }^{3,4^{*}}$
}

\footnotetext{
${ }^{1}$ Slovenian Museum of Natural History, Prešernova 20, P.O. Box 290, SI-1001 Ljubljana, Slovenia. E-mail: ttrilar@pms-lj.si

${ }^{2}$ Slovenian Academy of Sciences and Art, Novi trg 3, SI-1000 Ljubljana, Slovenia. E-mail: matija.gogala@guest.arnes.si

${ }^{3}$ Natural History Museum of the University of Florence, Zoology, "La Specola", Via Romana 17, I-50125 Florence, Italy. E-mail: francescagraziani78@gmail.com, ceccolinif@virgilio.it, cianferoni.fabio@gmail.com

${ }^{4}$ Research Institute on Terrestrial Ecosystems, CNR National Research Council of Italy, Via Madonna del Piano 10, I-50019 Sesto Fiorentino (FI), Italy

*corresponding author: cianferoni.fabio@gmail.com, fabio.cianferoni@unifi.it
}

KEY WORDS: Hemiptera, Cicadidae, singing cicadas, fauna, bioacoustics, Kefalonia Island, Greece.

КЛЮЧЕВЫЕ СЛОВА: Неmiptera, Cicadidae, сигналы, биоакустика, фауна, остров Кефалиния, Греция.

ABSTRACT. No cicada records for the Greek Ionian island of Kefalonia existed so far. The fauna of singing cicadas (Hemiptera: Cicadidae) of Kefalonia island (Cephalonia) has been investigated on the field excursions in 2010, 2016 and 2018 with classic and bioacoustic methods, using recording equipment for sonic range and ultrasonic detectors. We discovered 5 species: Lyristes plebejus (Scopoli, 1763), Cicada orni Linnaeus, 1758, Cicadatra atra (Olivier, 1790), Dimissalna dimissa (Hagen, 1856), and Tettigettula pygmea (Olivier, 1790).

РЕЗЮМЕ. До сих пор не было сведений о цикадах острова Кефалония (Ионическое море, Греция). Во время полевых работ в 2010, 2016 и 2018 гг. изучена фауна певчих цикад (Hemiptera: Cicadidae) острова Кефалония (Cephalonia) с помощью классических методов и методов биоакустики, с использованием записывающего оборудования для звукового и ультразвукового диапазона. Обнаружено 5 видов: Lyristes plebejus (Scopoli, 1763), Cicada orni Linnaeus, 1758, Cicadatra atra (Olivier, 1790), Dimissalna dimissa (Hagen, 1856) и Tettigettula pygmea (Olivier, 1790).

\section{Introduction}

Greece is in a key position in the Mediterranean, one of Earth's biodiversity hotspot [see Myers et al., 2000]. Also singing cicadas (Hemiptera: Cicadidae) are well represented in Greece [Jach, 2013] but, despite their large size and strong acoustic impact, in recent years only several studies have been conducted on these insects in the country, dealing mainly with bioacoustics and providing the description of several new species [e.g. Gogala et al., 2008, 2009, 2011, 2012, 2013, 2017; Gogala, Drosopulos, 2006; Gogala, Trilar, 2014; Quartau, Simões, 2005; Simões et al., 2000, 2006, 2013; Simões, Quartau, 2008, 2013; Trilar, Gogala, 2010].

However, there are no cicada studies focused on Ionian Islands and, to date, no data have been published for Kefalonia island (Cephalonia, Kefallinia or Kephal-

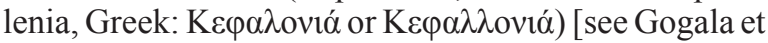
al., 2017], which is the largest of the Ionian Islands in western Greece and the $6^{\text {th }}$ largest island in Greece [see Cianferoni, 2019].

The present work lists the first records of cicadas for Kefalonia.

How to cite this article: Trilar T., Gogala M., Graziani F., Ceccolini F., Cianferoni F. 2020. First data on Cicadas of Kefalonia, Greece (Hemiptera: Cicadidae), including bioacoustics // Russian Entomol. J. Vol.29. No.1. P.1219. doi: $10.15298 /$ rusentj.29.1.03 


\section{Material and methods}

In the years 2010, 2016 and 2018 we investigated the singing cicadas of Kefalonia Island. In the periods from July 13. to 15., 2010 and in August 5. to 14., 2016 we (TT and MG) conducted the field work with the use of classical and bioacoustic methods. Additional field work was done (FG, FC and FC) in the period July, 22. to 25., 2018 (Fig. 1).

For the sound recordings we used microphones sensitive in sonic range (Telinga Pro 6 stereo, parabola diameter $57 \mathrm{~cm}$ ) and in ultrasonic range (ultrasonic detector Pettersson D-200 with microphone mounted in front of a Telinga reflector $(57 \mathrm{~cm}$ diameter) or smaller metal reflector (15 cm diameter)) in combination with Solid State recorders Marantz PMD660 and Zoom H2. For sound analyses we used Raven 1.5 (Cornell Lab of Ornithology), Amadeus Pro 1.3 (HairerSoft), Wave Pad (NHC Software) and Seewave package [Sueur et al., 2008] as a part of R statistic software. Using these methods we were able to get much more representative data about the presence and distribution of singing cicadas.

We first localized cicadas acoustically, recorded and then collected them with an entomological net if possible. Morphological investigations were made on dry prepared specimens. Higher classification and morphological terminology are after Moulds [2005].

The specimens collected in the field work are preserved in the collection of the Slovenian Museum of Natural History in Ljubljana, Slovenia, and in the private collections of some of the authors: Filippo Ceccolini in Rassina (Arezzo), Italy, Fabio Cianferoni and Francesca Graziani in Florence, Italy. All the sound recordings are stored in the Wildlife Sound Archive of

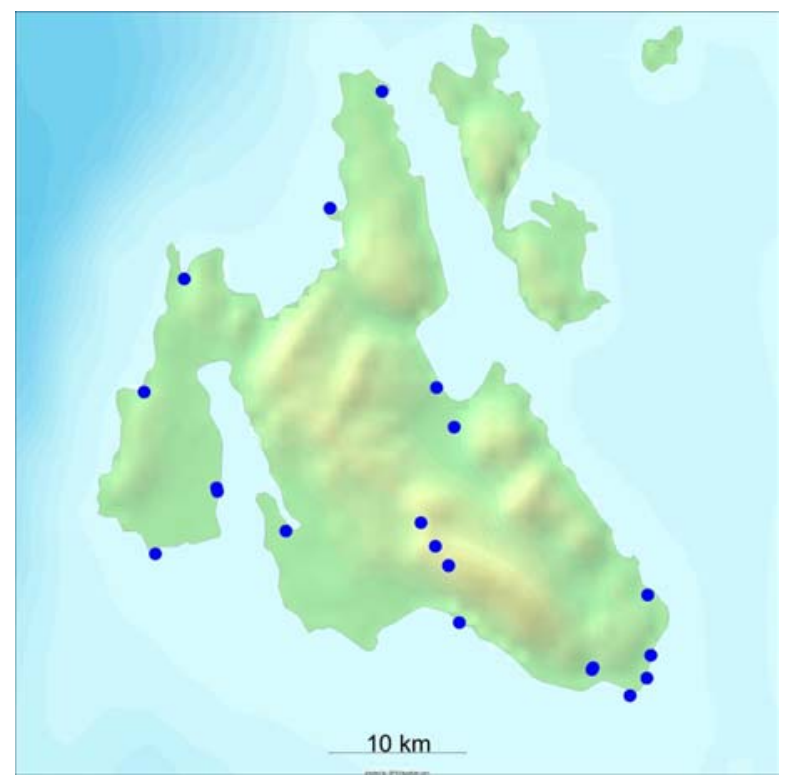

Fig. 1. Localities investigated during our field excursions to Kefalonia 2010, 2016 and 2018.

Рис. 1. Места сбора материала на о.Кефалония в 2010, 2016 и 2018 гг.
Slovenian Museum of Natural History in Ljubljana. Selected sound samples are available also on the web pages Songs of the European singing cicadas: $<$ http:// www.cicadasong.eu/>.

For each locality, the following information is given: locality name, coordinates, elevation (a.s.1.), date, type of data (song recorded, song heard, photographed or collected), number of specimens if collected, repository or source and collectors of the data. Geographical coordinates are in decimal degrees (datum WGS84). Number of decimals varies according to the accuracy of the data. The uncertainty (in metres) of the data was indicated according to the point-radius method [Wieczorek et al., 2004].

Distribution maps were created with GPS Visualizer [Schneider, 2003-2016], spectrogram and oscillogram with Seewave package [Sueur et al., 2008] as a part of R statistic software.

Abbreviations used in material examined:

PMSL = Slovenian Museum of Natural History, Ljubljana, Slovenia

$\mathrm{CFCC}=\mathrm{F}$. Ceccolini collection, Rassina (Arezzo), Italy

$\mathrm{CFCF}=\mathrm{F}$. Cianferoni collection, Florence, Italy

$\mathrm{CFGR}=\mathrm{F}$. Graziani collection, Florence, Italy

un. $=$ uncertainty

\section{Species account}

\author{
Subfamily Cicadinae \\ Lyristes plebejus (Scopoli, 1763) \\ Figs 2-3.
}

MATERIAL EXAMINED. Assos, Assos Fortress, 38.382833 $\mathrm{N} 20.533983^{\circ} \mathrm{E}$ (un. $=10 \mathrm{~m}$ ), $142 \mathrm{~m}, 8$.VIII.2016, song heard, photographed, T. Trilar, K. Prosenc Trilar; Lixouri, $38.198567^{\circ} \mathrm{N}$ $20.438733^{\circ} \mathrm{E}$ (un. $=10 \mathrm{~m}$ ), $5 \mathrm{~m}, 9 . \mathrm{VIII} .2016$, song heard, T. Trilar, K. Prosenc Trilar; Petani, $38.2612^{\circ} \mathrm{N} 20.3780^{\circ} \mathrm{E}$ (un. $=5 \mathrm{~m}$ ), $10 \mathrm{~m}$, 25.VII.2018, photographed, F. Graziani.

GENERAL DISTRIBUTION. It occurs in the southwestern part of Europe, in Portugal and Spain and extends its distribution range to northern and eastern Mediterranean [Nast, 1972; Boulard, 1995a, b; Gogala, 1998, 2002]; L. plebejus was recorded also for SE Azerbaijan [Tishechkin, 2003] but Simões and Quartau [2013] and Gogala and Trilar [2014] stated that from east Aegean L. plebejus is replaced by the related L. gemellus Boulard, 1988. Further research it is therefore necessary to shed light on the exact distribution of these two species (cf. also with the range of L. plebejus provided by Kudryashova [1979]).

REMARKS. The species occurs mainly in closed high shrubland and woodland on different plants, like olive trees, pine trees, oaks, as well as on fruit trees [Sueur et al., 2004; Drosopoulos et al., 2005; Simões et al., 2013].

\section{Cicada orni Linnaeus, 1758}

Figs 4-7.

MATERIAL EXAMINED. Agia Paraskevi bay, $38.26408^{\circ} \mathrm{N}$ $20.62328^{\circ} \mathrm{E}$ (un. $=10 \mathrm{~m}$ ), $10 \mathrm{~m}, 15$.VII.2010, song heard, $\mathrm{M}$. Gogala, T. Trilar, K. Šporar, S. Drosopoulos; Ainos Mt., 38.14711 ${ }^{\circ}$ $\mathrm{N} 20.63342^{\circ} \mathrm{E}$ (un $=10 \mathrm{~m}$ ), $1320 \mathrm{~m}, 14$.VII.2010, song recorded, M. Gogala, T. Trilar, K. Šporar, S. Drosopoulos; Argostoli, $38.17008^{\circ}$ $\mathrm{N} 20.49685^{\circ} \mathrm{E}$ (un. $=50 \mathrm{~m}$ ), $4 \mathrm{~m}, 25$. VII.2018, song heard, F. Ceccolini, F. Cianferoni, F. Graziani; Assos, Assos Fortress, $38.382833^{\circ} \mathrm{N} 20.533983^{\circ} \mathrm{E}$ (un. $=10 \mathrm{~m}$ ), $142 \mathrm{~m}, 8$.VIII.2016, song 


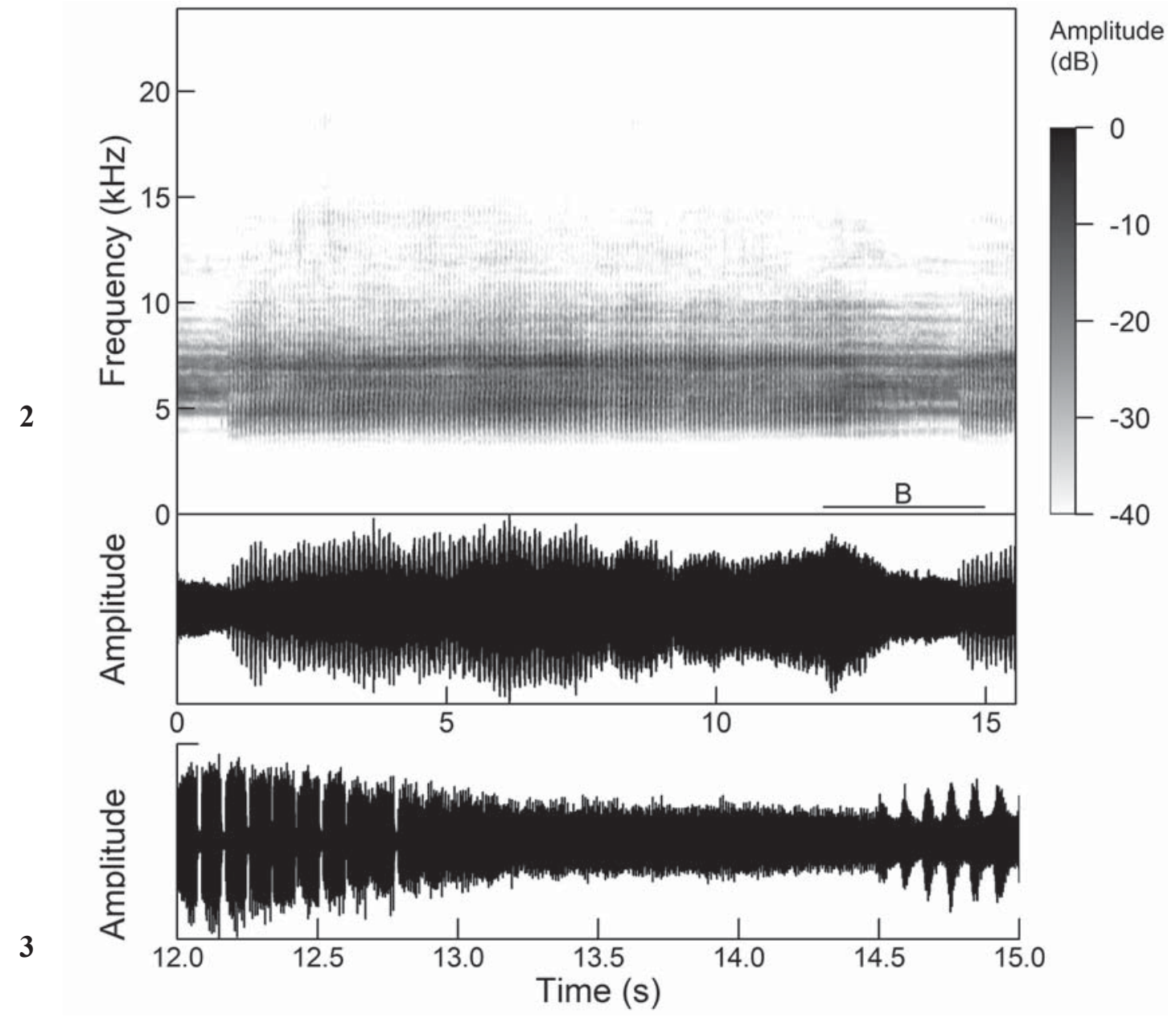

Figs 2-3. Lyristes plebejus: 2 - spectrogram of the calling song, showing one phrase; 3 - oscillogram of the enlarged section B of the calling song, showing the end of one phrase and the beginning of another.

Рис. 2-3. Lyristes plebejus: 2 - сонограмма призывного сигнала, показана одна фраза; 3 - осциллограмма части призывного сигнала (увеличенный сектор В сонограммы), показывающая конец одной фразы и начало следующей.

heard, T. Trilar, K. Prosenc Trilar; Atheras, Atheras beach, $38.33588^{\circ}$ $\mathrm{N} 20.41174^{\circ} \mathrm{E}$ (un. $=10 \mathrm{~m}$ ), $5 \mathrm{~m}, 11 . \mathrm{VIII} .2016$, song heard, $\mathrm{T}$. Trilar, K. Prosenc Trilar; Cape Akrotiri, $38.14928^{\circ} \mathrm{N} 20.38751^{\circ} \mathrm{E}$ (un. $=10 \mathrm{~m}$ ), $3 \mathrm{~m}, 9$. VIII.2016, song heard, T. Trilar, K. Prosenc Trilar; Fiskardo, $38.459933^{\circ} \mathrm{N} 20.577417^{\circ} \mathrm{E}$ (un. $=10 \mathrm{~m}$ ), $11 \mathrm{~m}$ 8.VIII.2016, song heard, T. Trilar, K. Prosenc Trilar; Kateleios, $38.07968^{\circ} \mathrm{N} 20.75436^{\circ} \mathrm{E}$ (un. $=20 \mathrm{~m}$ ), $40 \mathrm{~m}, 22$. VII.2018, photographed, F. Graziani; Lixouri, $38.196067^{\circ} \mathrm{N} 20.439433^{\circ} \mathrm{E}$ (un. $=$ $10 \mathrm{~m}), 2 \mathrm{~m}, 14 . \mathrm{VIII} .2016$, collected 1 male 1 female 1 exuvia (PMSL), T. Trilar, K. Prosenc Trilar; Lixouri, $38.198567^{\circ} \mathrm{N}$ $20.438733^{\circ} \mathrm{E}$ (un. $=10 \mathrm{~m}$ ), $5 \mathrm{~m}$, 9.VIII.2016, song heard, T. Trilar, K. Prosenc Trilar; Lourdata, Lourdas beach, $38.10949^{\circ} \mathrm{N} 20.64232^{\circ}$ $\mathrm{E}$ (un. $=10 \mathrm{~m}$ ), $4 \mathrm{~m}, 13$.VIII.2016, song heard, T. Trilar, K. Prosenc Trilar; Ainos Mt., $38.12649^{\circ} \mathrm{N} 20.69705^{\circ} \mathrm{E}$ (un. $=10 \mathrm{~m}$ ), $1266 \mathrm{~m}$, 6.VIII.2016, song heard, T. Trilar, K. Prosenc Trilar; Ainos Mt., $38.15980^{\circ} \mathrm{N} 20.62222^{\circ} \mathrm{E}$ (un. $=10 \mathrm{~m}$ ), $1039 \mathrm{~m}, 6$. VIII.2016, song heard, T. Trilar, K. Prosenc Trilar; Petani, $38.26120^{\circ} \mathrm{N} 20.37800^{\circ}$ $\mathrm{E}$ (un. $=5 \mathrm{~m}$ ), $10 \mathrm{~m}, 25$.VII.2018, song heard, F. Ceccolini, F. Cianferoni, F. Graziani; Rhoudi Mt., $38.17538^{\circ} \mathrm{N} 20.61023^{\circ} \mathrm{E}$ (un. $=10 \mathrm{~m}$ ), $1021 \mathrm{~m}, 14$.VII.2010, song heard, M. Gogala, T. Trilar, K. Šporar, S. Drosopoulos; Sami, $38.23871^{\circ} \mathrm{N} 20.63811^{\circ} \mathrm{E}$ (un. $=10$ $\mathrm{m}), 19 \mathrm{~m}, 13$.VII.2010, collected 1 female (PMSL), M. Gogala, T. Trilar, K. Šporar, S. Drosopoulos; Skala, $38.07278^{\circ}$ N $20.79949^{\circ}$ E (un. $=10 \mathrm{~m}$ ), $12 \mathrm{~m}$, 7.VIII.2016, song heard, T. Trilar, K. Prosenc Trilar; Skala, c/o Kako (or Kato) Beach, $38.0878^{\circ} \mathrm{N} 20.8029^{\circ} \mathrm{E}$ (un. $=10 \mathrm{~m}), 5 \mathrm{~m}, 24$.VII.2018, song heard, F. Ceccolini, F. Cianferoni, F. Graziani; Skala, near Kako (or Kato) Lagadi, $38.12766^{\circ} \mathrm{N}$

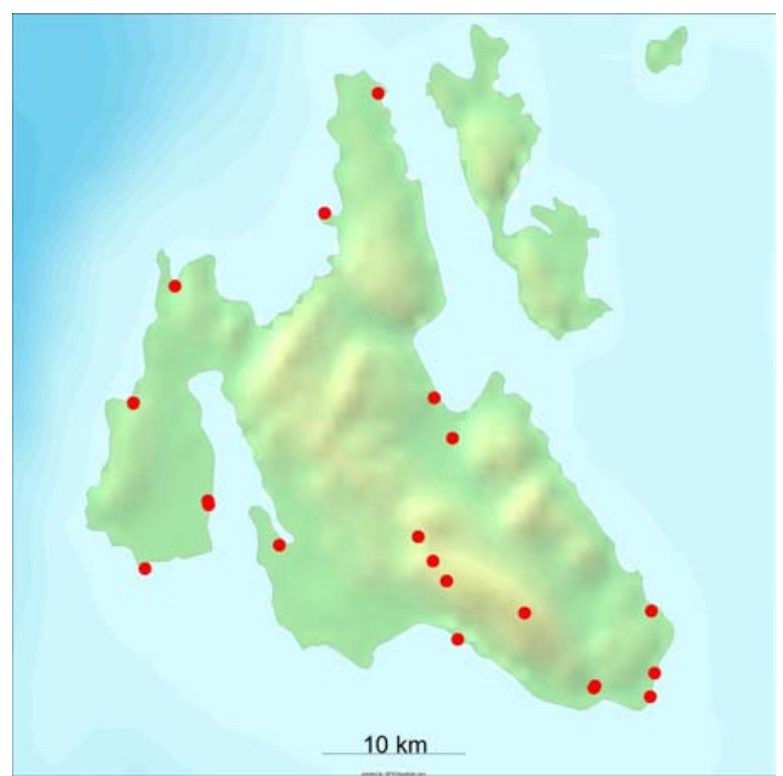

Fig. 4. Map with localities of Cicada orni on Kefalonia. Рис. 4. Места находок Cicada orni на о.Кефалония. 


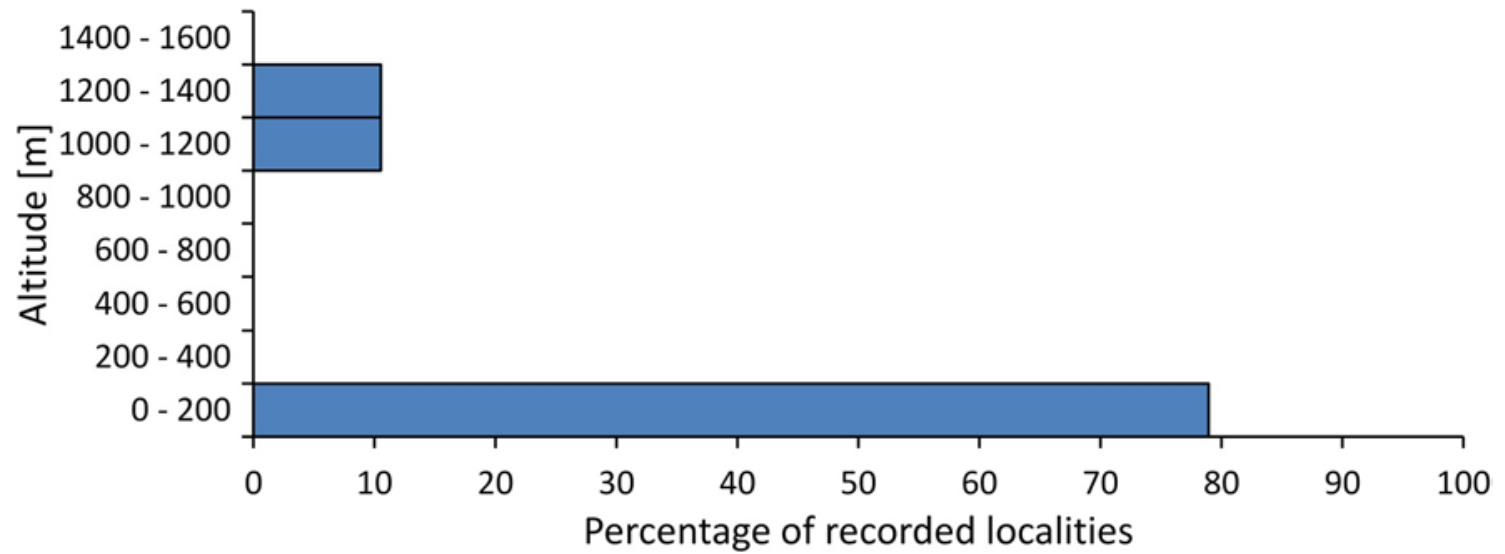

Fig. 5. Vertical distribution of Cicada orni on Kefalonia island per $200 \mathrm{~m}$ altitudinal belt.

Fig. 5. Распределение Cicada orni по высотным поясам (200 м) на о.Кефалония.

6

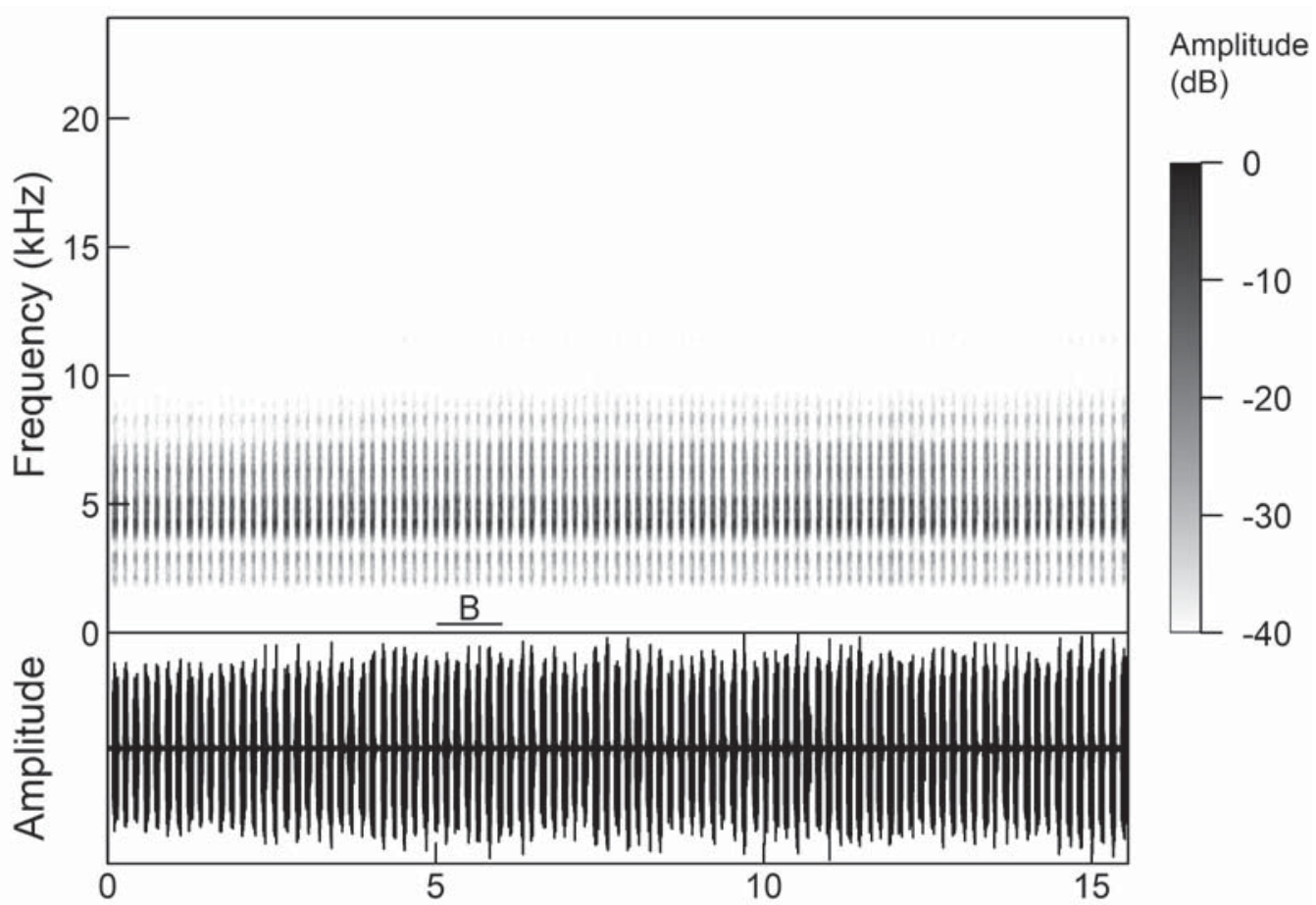

7

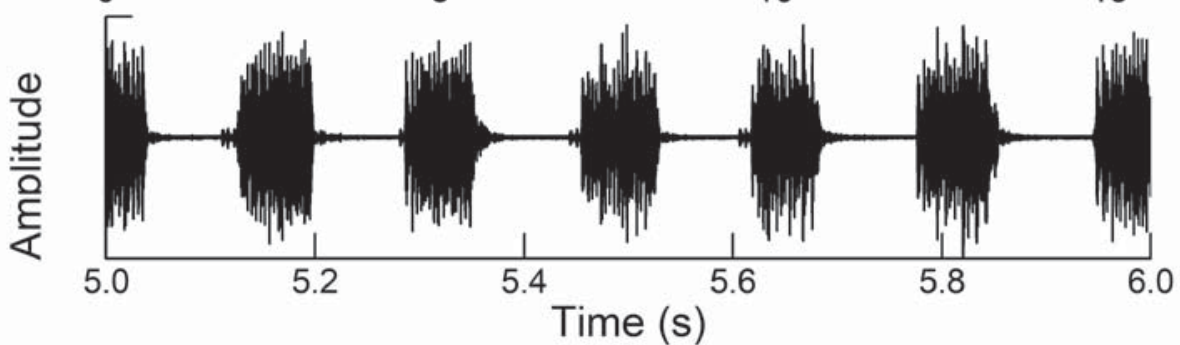

Figs 6-7. Cicada orni: 6 - spectrogram of the calling song; 7 - oscillogram of the enlarged part (section B of the figure 6) of the calling song.

Рис. 6-7. Cicada orni: 6 - сонограмма призывного сигнала; 7 - осциллограмма части (увеличенный сектор В сонограммы на рис. 6) призывного сигнала.

$20.80025^{\circ} \mathrm{E}$ (un. $=5 \mathrm{~m}$ ), $24 \mathrm{~m}, 24$ VII.2018, collected 4 males $(2$ CFCC, 1 CFCF, 1 CFGR), F. Ceccolini, F. Cianferoni, F. Graziani.

GENERAL DISTRIBUTION. This is one of the most abundant and common cicada species throughout the Medi- terranean area [Pinto-Juma et al., 2005], distributed from the Iberian Peninsula to western Greece and Turkey [Quartau et al., 1999], in some countries in the Near East [Nast, 1972], also around the Black Sea [Popov, 1975], North Caucasus 
[Tishechkin, 2003], Transcaucasia, Northwestern Iran and the Western Kopet-Dagh Mtn. Range in Turkmenistan [Kudryashova, 1979]. From east Aegean to the East C. orni seems to be replaced by the sibling species $C$. mordoganensis Boulard, 1979 [Simões et al., 2000; Gogala, Trilar, 2014].
REMARKS. It occurs in closed high shrubland and woodland on several species of plants (e.g. pine trees, olive trees, oaks, eucalyptus, vineyards) [Patterson et al., 1997; Puissant, Sueur, 2001; Sueur et al., 2004; Pinto-Juma et al., 2005].

8

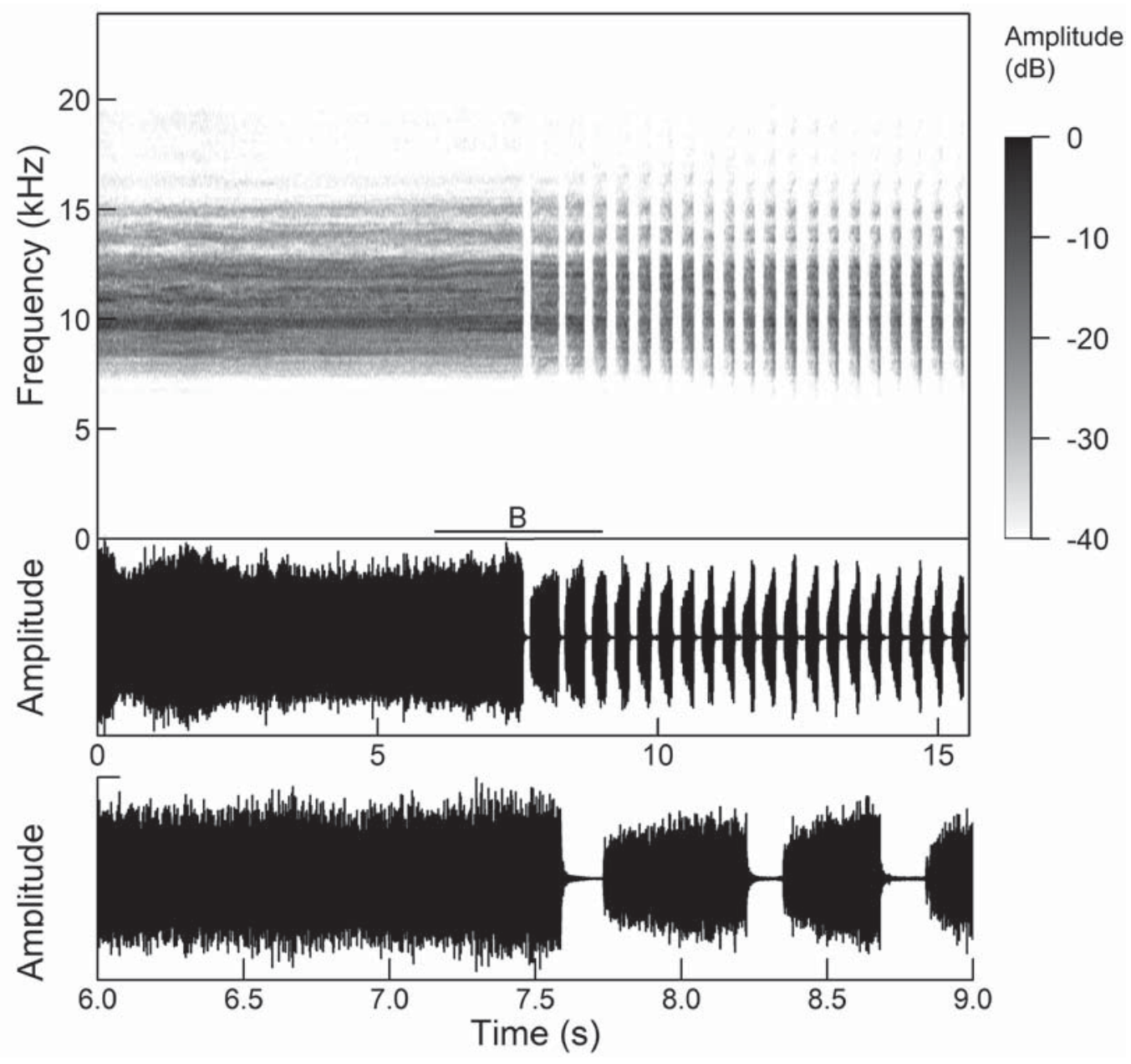

Figs 8-9. Cicadatra atra: 8 - spectrogram of the calling song, showing transition from continuous song to the part with short echemes; 9 - oscillogram of the enlarged part (section B of the figure 8) of the calling song.

Pис. 8-9. Cicadatra atra: 8 - сонограмма призывного сигнала, показан переход от непрерывного звука к серии коротких импульсов; 9 - осциллограмма части (увеличенный сектор В сонограммы) призывного сигнала.

Cicadatra atra (Olivier, 1790)

Figs 8-9.

MATERIAL EXAMINED. Agia Paraskevi bay, $38.26408^{\circ} \mathrm{N}$ $20.62328^{\circ} \mathrm{E}$ (un. $=10 \mathrm{~m}$ ), $10 \mathrm{~m}, 15 . \mathrm{VII} .2010$, song heard, M Gogala, T. Trilar, K. Šporar, S. Drosopoulos; Skala, Kaminia beach, $38.06133^{\circ} \mathrm{N} 20.78548^{\circ} \mathrm{E}$ (un. $=10 \mathrm{~m}$ ), $20 \mathrm{~m}, 14$. VII.2010, song recorded, M. Gogala, T. Trilar, K. Sporar, S. Drosopoulos; Kateleios, $38.07968^{\circ} \mathrm{N} 20.75436^{\circ} \mathrm{E}$ (un. $=20 \mathrm{~m}$ ), $40 \mathrm{~m}, 22$. VII. 2018 , photographed, F. Graziani.

GENERAL DISTRIBUTION. This species has a turaniceuropean distribution [Gogala, Gogala, 1999].

REMARKS. This polyphagous species occurs among various shrubs and low-growing trees [Holzinger et al., 2003].

\section{Subfamily Cicadettinae \\ Dimissalna dimissa (Hagen, 1856)}

Figs 10-11.

MATERIAL EXAMINED. Ainos Mt., $38.14713^{\circ} \mathrm{N} 20.63341^{\circ}$ $\mathrm{E}$ (un. $=10 \mathrm{~m}$ ), $1320 \mathrm{~m}, 14$.VII.2010, recorded, M. Gogala, T. Trilar, K. Šporar, S. Drosopoulos.

GENERAL DISTRIBUTION. This species occurs from France, Italy (including Sicily), Balkans, Crete [Gurcel, 2011], and in NE Caucasus [Tishechkin, 2003]. The records from Kazakhstan and Central Asia [Chelpakova, 1996; Mityaev, 1971] are doubtful since they could refer to unidentified Central-Asiatic closely related species [D. Tishechkin, pers. com.]. 


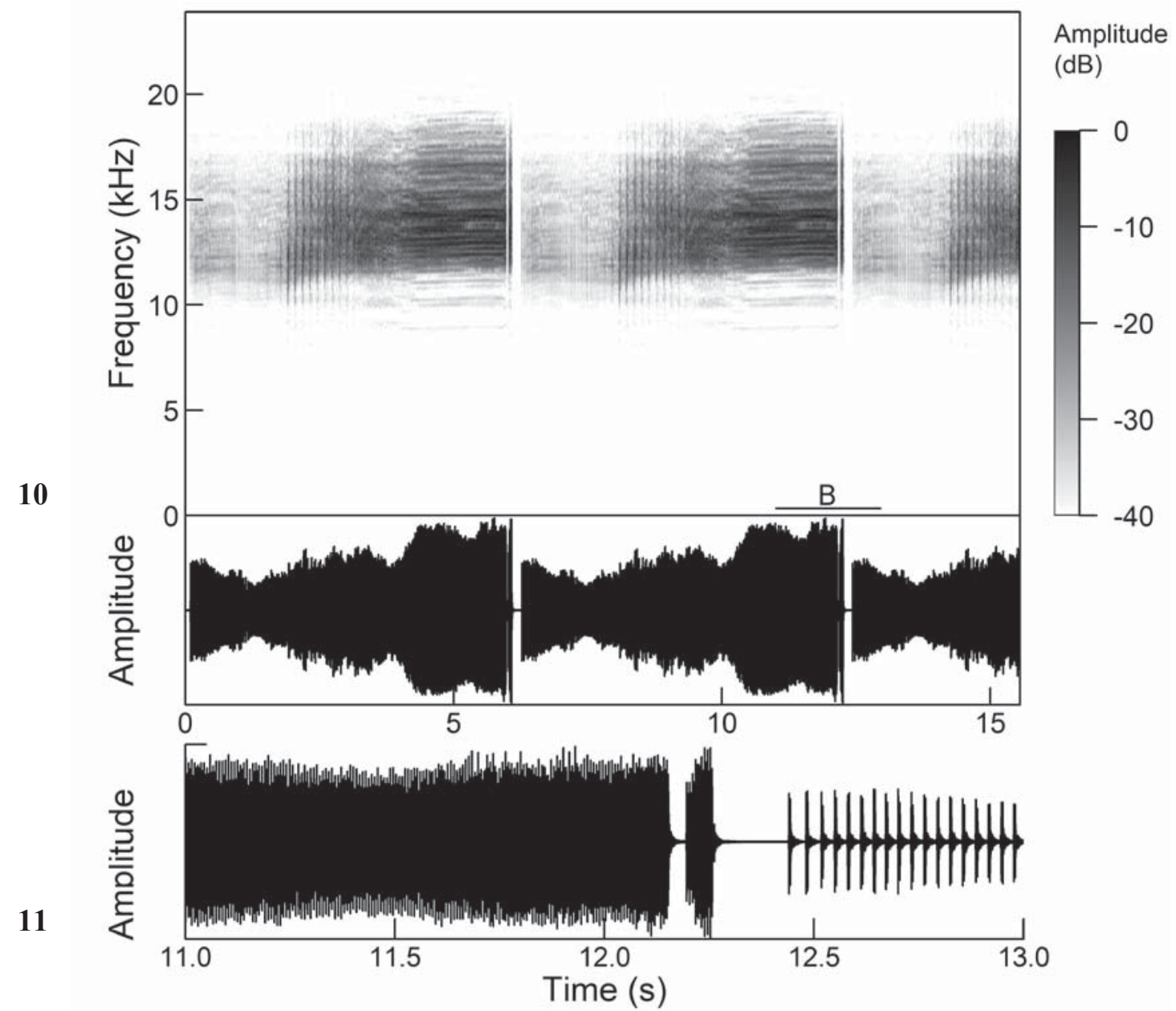

Figs 10-11. Dimissalna dimissa: 10 - spectrogram of the calling song; 11 - oscillogram of the enlarged part (section B of the figure 10) of the calling song, showing the end of one phrase and the beginning of another.

Рис. 10-11. Dimissalna dimissa: 10 - сонограмма призывного сигнала; 11 - осциллограмма части (увеличенный сектор В сонограммы) призывного сигнала, показывающая конец одной фразы и начало следующей.

REMARKS. The species occurs high up in the tree canopies [Trilar, Gogala, 2008].

\section{Tettigettula pygmea (Olivier, 1790) Figs 12-13.}

MATERIAL EXAMINED. Skala, Kaminia beach, $38.06133^{\circ} \mathrm{N}$ $20.78548^{\circ} \mathrm{E}$ (un. $=10 \mathrm{~m}$ ), $20 \mathrm{~m}, 14$. VII.2010, recorded, M. Gogala, T. Trilar, K. Šporar, S. Drosopoulos.

GENERAL DISTRIBUTION. This species is known from Southern Europe, although records from Spain are doubtful [Puissant, Sueur, 2010].

REMARKS. It occurs mainly in xeric sub-humid habitat [Puissant, Sueur, 2010].

\section{Discussion}

During the field excursions we discovered 5 species on Kefalonia island: Lyristes plebejus, Cicada orni, Cicadatra atra, Dimissalna dimissa, and Tettigettula pygmea. Although all the species are common in East Mediterranean and widely distributed also in the Greece mainland, they are recorded here for the first time for Kefalonia, where no records of singing cicadas existed so far.
It is clearly visible from the map of localities visited during our field excursions (2010, 2016 and 2018) in Kefalonia island (Fig. 1), from the distribution map (Fig. 4) and altitudinal distribution chart (Fig. 5) of Cicada orni on the island, that Kefalonia is not investigated sufficiently, there is a particular lack of midelevation localities (from 100 to 1000 metres) (Fig. 5).

Surprisingly, we did not detect any species of Cicadetta montana complex on Kefalonia island, despite very nice and suitable habitat on Ainos Mountain, which is overgrown with an old forest of Greek Fir (Abies cephalonica Loudon). The reason can be field work conducted rather late in the cicada season (second half of July and August). There is urgent need to visit the island in the second half of May and in June in order to search for the possible occurrence of species of the Cicadetta montana complex.

Moreover, to further improve our knowledge on singing cicadas of Kefalonia, any data from other collections (if exists) should be included and more field work with the use of bioacoustic methods should be done in the future. 


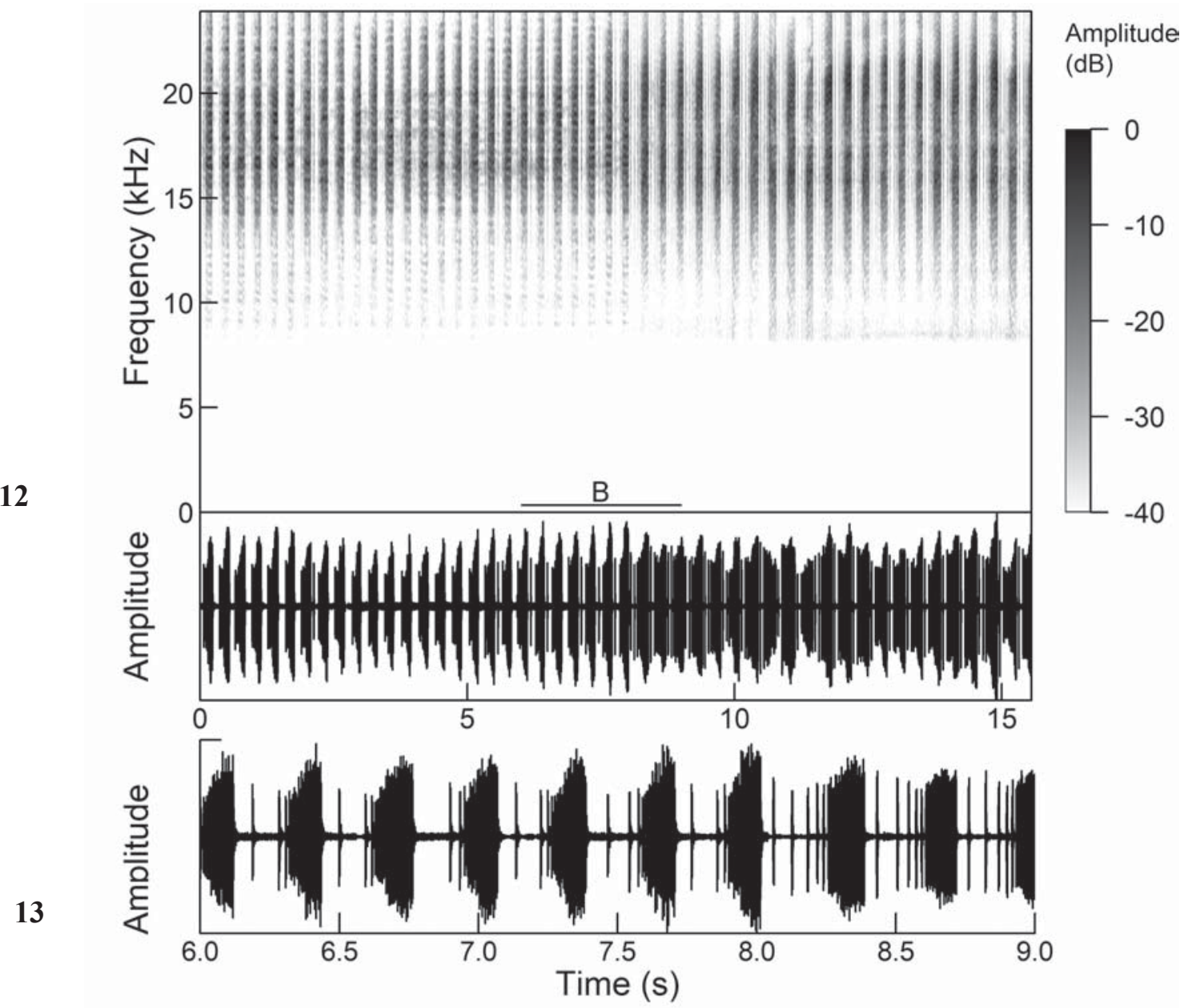

Figs 12-13. Tettigettula pygmea: 12 - spectrogram of the calling song; 13 - oscillogram of the enlarged part (section B of the figure 12) of the calling song.

Pис. 12-13. Tettigettula pygmea: 12 - сонограмма призывного сигнала; 13 - осциллограмма части (увеличенный сектор В сонограммы) призывного сигнала.

Acknowledgements. Our field research was supported by the Slovenian Museum of Natural History and Slovenian Academy of Sciences and Arts. The research of the first author (TT) was part of the programme "Communities, relations and communications in the ecosystems" (No. P1-0255) financed by the Slovenian Research Agency.

Special thanks go to the late Prof. Dr. Sakis Drosopoulos who supported and shared our research on cicadas in Greece during many years. We are also very thankful to his life companion Hanneke Drosopoulou for her help and great hospitality. We would like to thank Katarina Prosenc Trilar and Katja Šporar, who accompanied us in the field and helped us with logistics. We are also grateful to Dr. Andrej Gogala (Slovenian Museum of Natural History, Ljubljana), who made the preparation of the material.

Furthermore, we want to thank the reviewer Dr. Dmitri Tishechkin for helpful comments which improved the manuscript.

\section{References}

Boulard M. 1995a. Postures de cymbalisation, cymbalisations et cartes d'identité acoustique de cigales. 1 Généralités et espèces méditerranéennes (Homoptera, Cicadidae) // EPHE Biologie et Evolution des Insectes, Vol.7/8. P.1-72.

Boulard M., Mondon B. 1995b. Vies \& memoires de cigales: Provence, Languedoc, Mediterranean. Barbentane: Equinoxe. $159 \mathrm{pp}$.

Chelpakova Z.M. 1996. [Podotryad Cicadinea (Auchenorrhyncha) Cikadovy'e] // Kadastr geneticheskogo fonda Ky'rgy'zstana. Bishkek. T.3. P.33-47 [in Russian].

Cianferoni F. 2019. Review of the aquatic Hemiptera from Cephalonia, with a checklist for the Ionian Islands, Greece (Heteroptera: Gerromorpha, Nepomorpha, Leptopodomorpha) // Zootaxa. Vol.4576. No.1. P.46-60.

Drosopoulos S., Eliopoulos E., Tsakalou P. 2005. Is Migration Responsible for the Peculiar Geographical Distribution and Speciation Based on Acoustic Divergence of Two Cicadas in the Aegean Archipelago? // S. Drosopoulos, M.F. Claridge (eds.). Insect Sounds and Communication: Physiology, Behaviour, Ecology, and Evolution. Boca Raton: CRC Press. P.219-226.

Gogala M. 1998. Pojoči škržati Slovenije [Singing cicadas of Slovenia] // Proteus. No.60. P.392-399.

Gogala M. 2002. Gesänge der Singzikaden aus Südost- und MittelEuropa // Denisia 04, zugleich Kataloge des OÖ. Landesmuseums, Neue Folge. Bd.176. S.241-248.

Gogala M., Gogala A. 1999. A checklist and provisional atlas of the Cicadidae fauna of Slovenia (Homoptera: Auchenorrhyncha) // Acta Entomologica Slovenica. Vol.7. No.2. P.119-128. 
Gogala M., Trilar T. 2014. Distribution of endemic cicadas (Hemiptera: Cicadidae) on Evia and adjacent islands in Greece // Acta entomologica slovenica. Vol.22. No.1. P.45-58.

Gogala M., Drosopoulos S., Trilar T. 2008. Cicadetta montana complex (Hemiptera, Cicadidae) in Greece - a new species and new records based on bioacoustics // Deutsche Entomologische Zeitschrift. Vol.55. No.1. P.91-100.

Gogala M., Drosopoulos S., Trilar T. 2009. Two mountains, two species: new taxa of the Cicadetta montana species complex in Greece (Hemiptera: Cicadidae) // Acta entomologica slovenica. Vol.17. No.1. P.13-28.

Gogala M., Drosopoulos S., Trilar T. 2012. Cicadivetta goumenissa, a new cicada species from Peloponesos, Greece (Hemiptera: Cicadidae) // Acta entomologica slovenica. Vol.20. No.1. P.5-16.

Gogala M., Drosopoulos S., Trilar T. 2013. New distributional and bioacoustic data abou Cicadivetta goumenissa from Peloponnese, Greece (Hemiptera, Cicadidae) // A. Popov, S. Grozeva, N. Simov, E. Tasheva (eds.). Advances in Hemipterology // ZooKeys. Vol.319. P.83-91. doi: 10.3897/zookeys.319.4452.

Gogala M., Drosopoulos S. 2006. Song of Cicadetta flaveola Brullé (Auchenorrhyncha: Cicadidae: Tibicinidae) from Greece // Russian Entomological Journal. Vol.15. No.3. P.275-278.

Gogala M., Puissant S., Trilar T. 2017. Revision and resurrection of the genus name Mezammira Fieber 1876 (Hemiptera: Cicadidae) with special focus on its species from Greece and the description of two new species // Acta entomologica slovenica. Vol.25. No.1. P.5-64.

Gogala M., Trilar T., Drosopoulos S. 2011. Two new species and a new genus of Cicadettini (Hemiptera, Cicadidae) from the Greek island of Evia // Deutsche Entomologische Zeitschrift. Vol.58. P.105-117.

Gurcel K. 2011. Dimissalna dimissa (Hagen 1856), dernière espèce de Cigale découverte en France, observée dans le département du Var (Hemiptera Cicadidae) // L’Entomologiste. Vol.67. No.2. P.105-108.

Holzinger W.E., Kammerlander I., Nickel H. 2003. The Auchenorrhyncha of Central Europe. Die Zikaden Mitteleuropas: Fulgoromorpha, Cicadomorpha Excl. Cicadellidae. Vol.1. LeidenBoston: Brill. 681 pp.

Jach M. 2013. Fauna Europaea: Cicadidae // H. Hoch (ed.). Fauna Europaea: Cicadomorpha. Fauna Europaea version 2017.06, https://fauna-eu.org

Kudryashova I.V. 1979. [Nymphs of singing cicadas of the fauna of USSR]. Moscow: Nauka Publ. 160 pp. [In Russian]

Mityaev I.D. 1971. [Cicadinea of Kazakhstan. Keys for identification of species]. Alma-Ata: "Nauka" Publ. 211 pp. [In Russian]

Myers N., Mittermeier R.A., Mittermeier C.G., da Fonseca G.A.B., Kent J. 2000. Biodiversity hotspots for conservation priorities // Nature. Vol.403. No.6772. P.853-858.

Nast J. 1972. Palaearctic Auchenorrhyncha (Homoptera), an annotated check list. Warszawa: Polish Scientific Publications. $551 \mathrm{pp}$.

Patterson I.J., Massei G., Genov P. 1997. The density of cicadas Cicada orni in Mediterranean coastal habitats // Italian Journal of Zoology. Vol.64. P.141-146.

Pinto-Juma G., Simões P.C., Seabra S.G., Quartau J.A. 2005. Calling Song Structure and Geographic Variation in Cicada orni Linnaeus (Hemiptera: Cicadidae) // Zoological Studies. Vol.44. No.1. P.81-94.
Popov A.A. 1975. The structure of the tymbals and the characteristics of the sound signals in singing cicadas (Homoptera, Cicadidae) in the southern regions of the USSR // Entomological Review. Vol.54. No.2. P.7-35.

Puissant S., Sueur J. 2001. Contribution $1^{\circ}$ étude des Cigales de Corse (Hemiptera, Cicadidae) // Bulletin de la Société entomologique de France. Vol.106. P.429-436.

Puissant S., Sueur J. 2010. A hotspot for Mediterranean cicadas (Insecta: Hemiptera: Cicadidae): new genera, species and songs from southern Spain // Systematics and Biodiversity. Vol.8. No.4. P.555-574.

Quartau J.A., Rebelo M.T., Simões P.C., Fernandes T.M., Claridge M.F., Drosopoulos S., Morgan J.C. 1999. Acoustic signals of populations of Cicada orni L. in Portugal and Greece (Hemiptera: Auchenorrhyncha: Cicadomorpha: Cicadidae) // Reichenbachia. Vol.33. No.8. P.71-80.

Quartau J.A., Simões P.C. 2005. Cicada cretensis sp. n. (Hemiptera, Cicadidae) from southern Greece // Biologia. Vol.60. No.5. P.489-494.

Schneider A. 2003-2019. GPS Visualizer // http://www.gpsvisualizer. com [20.12.2019].

Simões P.C., Quartau J.A. 2008. Distribution patterns and calling song variation in species of the genus Cicada linnaeus 1758 (Hemiptera, Cicadidae) in the aegean Sea area // Italian Journal of Zoology. Vol.75. No.2. P.135-146.

Simões P.C., Quartau J.A. 2013. Distribution of cicadas of the genus Lyristes (Hemiptera: Cicadidae) in the eastern Mediterranean area // Biologia. Vol.68. No.5. P.961-965.

Simões P.C., Boulard M., Quartau J.A. 2006. On the taxonomic status of Cicada orni Linnaeus (Hemiptera, Cicadidae) from Lesbos island in Greece // Zootaxa. Vol.1105. P.17-25.

Simões P.C., Boulard M.M., Rebelo M.T., Drosopoulos S., Claridge M.F., Morgan J.C., Quartau J.A. 2000. Differences in the male calling songs of two sibling species of Cicada (Hemiptera: Cicadidae) in Greece // European journal of Entomology. Vol.97. P.437-440.

Simões P.C., Sanborn A., Quartau J.A. 2013. Two new species of Cicadatra (Hemiptera: Cicadidae) from Greece // Entomological Science. Vol.16. P.83-90.

Sueur J., Puissant S., Simões P.C., Seabra S.G., Boulard M., Quartau J.A. 2004. Cicadas from Portugal: revised list of species with eco-ethological data (Hemiptera: Cicadidae) // Insect Systematics \& Evolution. Vol.35. P.177-187.

Sueur J., Aubin T., Simonis C. 2008. Seewave, a free modular tool for sound analysis and synthesis // Bioacoustics. Vol.18. No.2. P.213-226.

Tishechkin D.Yu. 2003. Vibrational communication in Cercopoidea and Fulgoroidea (Homoptera: Cicadina) with notes on classification of higher taxa // Russian Entomological Journal. Vol.12. No.2. P.129-181.

Trilar T., Gogala M. 2008. New data on singing cicadas (Hemiptera: Cicadidae) of Romania // Entomologica romanica. Vol.13. P.29-33.

Trilar T., Gogala M. 2010. Tettigetta carayoni Boulard (Hemiptera: Cicadidae) from Crete, faunistic data and first description of its song // Acta entomologica slovenica. Vol.18. No.1. P.5-18.

Wieczorek J., Guo Q., Hijmans R.J. 2004. The point-radius method for georeferencing locality descriptions and calculating associated uncertainty // International Journal of Geographical Information Science. Vol.18. No.8. P.745-767. 